Robert M. Rynkowski

Warszawa

DOI: $10.15290 /$ std.2015.01.13

\title{
ABRAHAMA J. HESCHELA ROZUMIENIE DIALOGU CZŁOWIEKA Z BOGIEM. WSKAZÓWKI DLA CHRZEŚCIJAŃSKIEJ ANTROPOLOGII
}

\section{ABRAHAM J. HESCHEL'S UNDERSTANDING OF THE DIALOGUE WITH GOD. TIPS FOR CHRISTIAN ANTHROPOLOGY}

What are the indelible content of any Christian anthropology? And as these days to talk about the content? Abraham J. Heschel did not think that evil is inscribed in human nature and that God is dead. However, he did not think that the world is basically good. He did not think that a man basically directed towards God. Abraham J. Heschel believed that God was banished from the world, a man killed his inner life and lost contact with God. If a man does not reflect the presence of God in the world, it reflects the image of the beast. The task of man is letting God into your world. God speaks to man through the Bible, and the man says to God in prayer. Abraham J. Heschel does not believe that prayer is a conversation with God himself (Clement). God's answer to prayer is interested in the life of man. Prayer makes God back into the world. Indelible content of Christian anthropology is the belief that man is capable of dialogue with God and that prayer to return God to the world. Modern man does not believe that God is close to him. People can convince the assertion that man in prayer becomes the object of the mind of God.

Key words: Christian anthropology, Abraham Joshua Heschel, prayer, dialogue, conversation. 
W artykule tym chciałbym nawiązać do pytania, jakie są - a może raczej jakie powinny być - nieusuwalne treści każdej chrześcijańskiej antropologii? Z tym pytaniem wiąże się również pytanie praktyczne: jak o tych nieusuwalnych treściach mówić w dzisiejszym świecie?

Za przewodnika na drodze do udzielenia tych odpowiedzi chcę jednak wybrać nie przedstawiciela teologii katolickiej czy chrześcijańskiej, ale Abrahama Jushuę Heschela, myśliciela żydowskiego, którego szczyt aktywności twórczej przypadł na lata 50. i 60. ubiegłego wieku. Wydaje się, że w pracach tego uczonego bardzo ważne - również w kontekście odpowiedzi na sformułowane pytania - jest przekonanie, że człowiek pozostaje w dialogu z Bogiem. Trzeba jednak od razu zwrócić uwagę na to, że w książkach Heschela słowo „dialog” pojawia się dość rzadko, że nie mówi on wprost o człowieku jako istocie dialogicznej $^{1}$. Z jednej strony to trudność dla tego, kto chce przedstawić Heschela rozumienie dialogu człowieka z Bogiem, ale $z$ drugiej - o czym będzie mowa dalej - pewna wskazówka dla chrześcijańskiej antropologii.

Sądzę, że dla kształtu poglądów tego autora ważna jest jego biografia, dlatego chcę ją krótko przedstawić.

\section{Biografia nie bez znaczenia}

Abraham J. Heschel urodził się w Warszawie 11 stycznia 1907 roku, był potomkiem słynnego rodu chasydzkich cadyków. W latach 30. ubiegłego wieku studiował w Berlinie (na dzisiejszym Uniwersytecie Humboldta) filozofię oraz dodatkowo historię sztuki i filologię semicką. W Hochschule fur die Wissenschaft des Judentums szkolił się w nowoczesnych badaniach naukowych nad żydowską literaturą i historią. 16 lipca 1934 roku Heschel zdał egzaminy ustne i otrzymał stopień rabina, obroniwszy pracę na temat Apokryfy, pseudoepigrafy $i$ halacha. 23 lutego 1933 roku, trzy tygodnie po dojściu Hitlera do władzy, złożył ustny egzamin doktorski. Z powodu antysemityzmu miał duże trudności z opublikowaniem swojej rozprawy doktorskiej Das prophetische Bewufltsein. Wiosną 1936 roku książka Die Prophetie została opublikowana przez Polską Akademię Umiejętności w Krakowie (w języku niemieckim, koszty pokryło Wydawnictwo Erich Reiss w Berlinie).

Po zakończeniu studiów uniwersyteckich Heschel mieszkał dalej w Berlinie. Wykładał w Hochschule, a także w Jüdisches Lehrhaus w Berlinie. 3 marca 1937 roku opuścił Berlin i przeniósł się do Frankfurtu, by przejąć katedrę po Martinie Buberze. Pod koniec października 1938 roku Żydzi mieszkający

W książce na temat Heschelowej filozofii człowieka W. Szczerbiński nie poświęca uwagi temu zagadnieniu. Por.: W. Szczerbiński, Abrahama Joshuy Heschela filozofia czlowieka, Lublin 2000. 
w Niemczech, ale posiadający polskie paszporty, zostali nagle aresztowani i deportowani do Polski. Przez następnych dziesięć miesięcy Heschel wykładał filozofię żydowską i Biblię w warszawskim Instytucie Nauk Judaistycznych. Zaledwie na sześć tygodni przed inwazją Niemiec na Polskę opuścił Warszawę i wyjechał do Londynu. W marcu 1940 roku, po otrzymaniu wizy amerykańskiej, Heschel przybył do Nowego Jorku. Objął posadę pracownika dydaktyczno-naukowego o specjalności z zakresu Biblii i filozofii żydowskiej w Hebrew Union College w Cincinnati. W ciągu następnych miesięcy otrzymał posadę w Jewish Theological Seminary w Nowym Jorku. W latach 50. zostały wydane najważniejsze jego książki: Pańska jest ziemia (1950, polski przekład: 1996), Człowiek nie jest sam (1951, polski przekład: 2001), Szabat (1951, polski przekład: 1994), Człowiek szukający Boga (1954, polski przekład: 2008), Bóg szukajacy człowieka (1955, polski przekład: 2007).

Adaptując swą pracę doktorską na temat proroków do publikacji w języku angielskim w latach 60. (The Prophets, 1962, polski przekład: 2014), doszedł do przekonania, że musi zaangażować się w sprawy ludzi, w ludzkie cierpienie. W styczniu 1963 roku po raz pierwszy spotkał Martina Luthera Kinga i stali się przyjaciólmi. Rozpoczął się długi okres zaangażowania Heschela w ruch na rzecz praw obywatelskich. Był przeciwnikiem wojny w Wietnamie i potępiał ją w licznych wystąpieniach. Słowa proroków, które rozważał i kontemplował, oderwały go od pracy naukowej i postawily w obliczu palących kwestii społecznych jego czasów. Wojna w Wietnamie, prawa człowieka, rasizm, ubóstwo, sytuacja Żydów w Związku Radzieckim, Izrael - wszystko to było bolesnym przedmiotem jego trosk, dla których poświęcał pracę naukową. Stał się głosem sumienia przemawiającym w imieniu „gnębionych biedaków”.

Utrzymywał bliskie relacje z chrześcijanami. Najważniejsze dokonania Heschela w dziedzinie relacji chrześcijańsko-żydowskich miały miejsce, kiedy zaangażował się w prace Soboru Watykańskiego II w połowie lat 60. Na zaproszenie American Jewish Committee poleciał do Rzymu, gdzie zaprzyjaźnił się $z$ kard. Augustynem Beą, kierującym pracami nad deklaracją na temat relacji Kościoła z religiami niechrześcijańskimi Nostra aetate. Spotkał się kilkakrotnie z papieżem Pawłem VI, a także z kard. Johannesem Willebrandsem z Holandii, i zajmował zdecydowane stanowisko w chwilach, kiedy wydawało się, że Sobór osłabia wymowę deklaracji w tym, co odnosi się do żydów. Przykładem estymy, jaką darzyli Heschela katolicy, może być - wśród innych wyrazów hołdu i czci po jego śmierci - poświęcony jego osobie numer periodyku „America”, co było wydarzeniem niezwykłym, czego nie uczyniono już w stosunku do żadnego innego żyda. Dla protestantów i katolików był bez wątpienia najbardziej szanowanym przedstawicielem judaizmu. Nie sposób zapomnieć o jego przyjaźni z Reinholdem Niebuhrem, teologiem ewangelickim. 
Dzień przed śmiercią Heschel, wbrew zakazom otoczenia, pojechał do Connecticut i stał na mrozie i śniegu przed bramą więzienia stanowego, ponieważ w tym dniu miał zostać wypuszczony na wolność jego przyjaciel, ksiądz, uwięziony za udział w demonstracji. Zmarł 23 grudnia 1972 roku we śnie.

Heschelowe doświadczenie rodzenia się ideologii totalitarnej, która doprowadziła do śmierci wielu milionów ludzi, w tym członków jego narodu i rodziny, nie wywołało u niego pesymizmu czy uznania, że zło jest wpisane w naturę człowieka, a Bóg umarł. Same tytuły jego najważniejszych prac pokazują, że był on przekonany, że Bóg i człowiek wzajemnie siebie poszukują i potrzebują. Wydaje się jednak, że to doświadczenie w ogromnej mierze przyczyniło się do tego, że świata nie widział jako zasadniczo dobrego i pogodnego, a człowieka jako zasadniczo skierowanego ku Bogu.

\section{Bóg wypędzony}

Dla Heschelowej antropologii istotne jest przekonanie o wypędzeniu Boga $z$ naszego świata, z którym to wypędzeniem wiąże się porzucenie upodobania w dobru. Przejmująco pisał o tym w 1943 roku²$^{2}$ :

Igraliśmy z Imieniem Bożym. Na próżno obieraliśmy ideały. Wołaliśmy do Pana. Przyszedł. I został zignorowany. Mówiliśmy kazania, ale stroniliśmy od Niego. Teraz zbieramy żniwo naszych zaniedbań. Przez wieki Jego głos był wołaniem na pustyni. Jakże zręcznie został pochwycony w sidła i uwięziony w miejscach sprawowania kultu! Jakże często był zagłuszany bądź przeinaczany! Teraz widzimy, jak stopniowo się wycofuje, opuszczając lud za ludem, uchodząc z ich serc, gardząc ich mądrością. Upodobanie w dobru prawie opuścilo ziemię. Ludzie piętrzą swą złość i okrucieństwo, dokładając do złych czynów coraz to nowe okropności³

Jego diagnoza sytuacji współczesnego człowieka, pozbawionego zdolności wiary, chociaż sformułowana w połowie ubiegłego wieku, zastanawiająco świeżo brzmi w czasach obecnych:

Pracowaliśmy nad udoskonaleniem silników, a dopuściliśmy do tego, że nasze życie wewnętrzne stało się wrakiem. Wyśmiewaliśmy przesądy, aż utraciliśmy zdolność wiary. Pomogliśmy zagasić światło, które zaświecili nasi ojcowie. Wymieniliśmy świętość na wygodę, wierność na sukces, miłość na władzę, mądrość na informację, tradycję na modę.

Żyjemy zatem w świecie, z którego Bóg został wypędzony, a człowiek zabił swoje życie wewnętrzne i utracił z Nim kontakt, przez co zaczął piętrzyć różne

2 Tekst zmodyfikowany zawarty jest w książce Człowiek szukający Boga. Szkice o modlitwie $i$ symbolach, wydanej w 1954 roku.

3 A. J. Heschel, Człowiek szukajacy Boga. Szkice o modlitwie i symbolach, Kraków 2008, s. 193.

4 Ibidem, s. 195. 
okropności. Można wręcz mówić o bezdomności człowieka i Boga we wszechświecie przenikniętym złem:

W obliczu tylu cierpień i zła, wobec niezliczonych przykładów życia niezgodnego $z$ wolą Bożą można było tylko doświadczyć niepokoju i poczucia duchowej bezdomności. Doświadczenie to wzmagało się, w miarę jak człowieka ożywiała świadomość, że sam Bóg jest bezdomny we wszechświecie, gdzie ludzie sprzeciwiają się Jego woli i odrzucają Jego królestwo. Szechinah [obecność Boga - R. M. R.] jest na wygnaniu, świat jest zepsuty, sam wszechświat nie jest u siebie w domu...5.

Heschel przekonuje jednak, że człowiek bez więzi z Bogiem nie istnieje, jeśli nie odzwierciedla Jego obecności w świecie, odzwierciedla obraz bestii:

Zapamiętajmy na zawsze, że zmysł świętości jest dla nas tak ważny jak światło słońca. Nie ma natury bez ducha, nie ma świata bez Tory. Nie ma braterstwa bez ojca, nie ma ludzkości bez przywiązania do Boga. Bóg do nas powróci, kiedy zechcemy Go wpuścić - do naszych banków i fabryk, do Kongresu i do klubów, do sądów i komisji śledczych, do naszych domów i teatrów. Bo Bóg jest wszędzie albo nie ma Go nigdzie, jest Ojcem wszystkich ludzi albo nie jest niczyim, troszczy się o wszystko albo o nic się nie troszczy. Jedynie w Jego obecności nauczymy się, że chwała człowieka nie polega na dążeniu do władzy, ale na zdolności do współczucia. Człowiek odzwierciedla albo obraz obecności Bożej, albo obraz bestii ${ }^{6}$.

Te sugestywne diagnozy żydowskiego myśliciela współczesnemu człowiekowi Zachodu, żyjącemu we w miarę bezpiecznym i wygodnym świecie, mogą wydać się mocno przesadzone i nieprawdziwe. A jednak również w tym świecie, świecie często bez Boga, zło nie zniknęło, zostało tylko zakamuflowane. Zygmunt Bauman w książce Nowoczesność $i$ Zagłada pokazuje, że nowoczesność ukrywa przed nami zło, które czynimy. A wtedy zaczynamy produkować je na skalę przemysłową. Najbardziej przejmującym tego przykładem, najbardziej spektakularnym przejawem naszej rosnącej obojętności i ślepoty moralnej stał się Holocaust. Nie był on bynajmniej wynikiem załamania się cywilizacji Zachodu, lecz jej niepowstrzymanego rozwoju. Doprowadziła do niego jak najbardziej nowoczesna ambicja zmierzająca do racjonalnego porządku społecznego, a także osłabienie tradycyjnych wspólnot oraz postęp nauki, techniki i biurokracji. Żaden $z$ tych procesów nie jest sam w sobie negatywny, żaden nie zapowiada Zagłady, ale razem tworzą „morderczą mieszankę”. Michał Łuczewski podkreśla:

Ale jeśli Bauman ma rację, jeśli nowoczesność jest tak gęboko zatruta, jej mordercze efekty muszą być widoczne tu i teraz. Zagłada nie nadchodzi, owszem, już jest. I wzbiera nieustannie. Nie musimy sobie wyobrażać niewyobrażalnego, możemy to zobaczyć. W tysiącach klinik aborcyjnych i szpitali na świecie trwa żmudna, nieustanna praca nowoczesności. Jej wynikiem jest jednocześnie produkcja i ukrywanie

5 Ibidem, s. 102.

6 Ibidem, s. 196. 
śmierci na masową skalę. Nowoczesność nigdy nie przestała - nie mogła przestać - pożerać własnych dzieci?

Człowiek nowoczesny ciągle odzwierciedla zatem obraz bestii...

\section{Modlitwa - odzyskanie więzi}

Oczywisty jest więc wniosek, że zadaniem człowieka jest odzyskanie więzi z Bogiem, przywołanie go do naszego świata, wpuszczenie Go do naszego życia. Jak jednak mogłoby to się dokonać? Według Heschela podstawą każdej religii jest żywa i dynamiczna relacja między Bogiem a człowiekiem. Najbardziej klasycznym świadectwem tej relacji jest Biblia. Nie można jednak właściwie zrozumieć tego, co zawarte jest w Biblii, jeśli nie odczuwa się jej słów jako skierowanych bezpośrednio do nas. Biblijne świadectwo relacji między Bogiem i człowiekiem będzie niezrozumiałe dla tego, kto nie będzie gotów sam wejść w relację z Bogiem, odpowiedzieć na wezwanie Boga ${ }^{8}$.

Heschel mówi tu bardziej o relacji niż dialogu, ale przytacza też pewien charakterystyczny cytat:

Ten, kto się modli, mówi do Boga; lecz do tego, kto czyta Biblię, mówi Bóg, jak powiedziano (Ps 119, 99): świadectwa Twoje są Twoją ze mną rozmową 9

Zatem dialog jest tutaj ukazany jako z jednej strony mówienie Boga do człowieka przez Biblię (człowiek ma odpowiedzieć na to wezwanie, ale jest to udzielenie odpowiedzi Bogu swoim życiem, czynem oraz konkretną postawą), a z drugiej strony jako mówienie człowieka do Boga w modlitwie. Znamy jednak klasyczną definicję modlitwy sformułowaną przez:

Jest zatem modlitwa, żeby się wyrazić tak zuchwale, rozmową z samym Bogiem. Choćbyśmy nawet tylko szeptem lub nawet nie otwierając ust przemawiali samym tylko milczeniem, w głębi duszy krzyczymy. Przecież Bóg słyszy bez żadnej przeszkody wewnętrzny głos naszego serca ${ }^{10}$,

która wydaje się jak najbardziej właściwa do wyrażenia bliskiego dialogu człowieka z Bogiem. Tyle że Heschel taką definicję podaje w wątpliwość, uważa, że modlitwę nie do końca można nazwać rozmową, dialogiem, w czym zbliża się do pojęcia modlitwy w ujęciu Sørena Kierkegaarda:

$7 \quad$ M. Łuczewski, Nowoczesna Zagłada (cyt. za: http://wyborcza.pl/magazyn/1, 140258, 16547751,Nowoczesna_Zaglada.html [dostęp: 01.09.2014]).

8 H. Halkowski, Postowie tlumacza, w: A. J. Heschel, Pańska jest ziemia. Wewnętrzny świat Żyda w Europie Wschodniej, Kraków 2010, s. 154n, por. A. J. Heschel, Bóg szukający człowieka. Podstawy filozofii judaizmu, Kraków 2007, s. 314-316.

$9 \quad$ A. J. Heschel, Bóg szukajacy czlowieka..., s. 316.

10 Klemens Aleksandryjski, Kobierce VII 39, 6. 
Modlitwa nie jest monologiem. Ale czy jest to dialog z Bogiem? Czy człowiek zwraca się do Niego tak jak osoba do osoby? Nie jest rzeczą właściwą opisywać modlitwę przez analogię z rozmową ludzką; my nie przekazujemy Bogu żadnych wiadomości. Sprawiamy tylko, że sami możemy być dla Boga przekazem. Modlitwa jest emanacją ku Bogu tego, co w nas najcenniejsze, to wylanie przed Nim serca. Nie jest to relacja między osobą a osobą, podmiotem a podmiotem, ale dążenie do tego, by stać się przedmiotem Jego myśli ${ }^{11}$.

Czy ten dialog-niedialog jest przydatny dla chrześcijańskiej antropologii, która chciałaby opisać człowieka jako zdolnego do dialogu z Bogiem?

Tyle że po głębszej refleksji musimy uznać, że w wielu punktach możemy się z Heschelem zgodzić.

Po pierwsze, musimy zgodzić się z tym, że w modlitwie nie przekazujemy Bogu żadnych nieznanych mu informacji, „albowiem wie Ojciec wasz, czego wam potrzeba, wpierw zanim Go poprosicie" (Mt 6, 8). Hermann Cohen zwrócił uwagę na to, że modlitwy nie można rozumieć jako ciągu zdań orzekających, których celem jest poinformowanie słuchaczy o jakimś stanie rzeczy (Bóg nie potrzebuje żadnej informacji od człowieka) bądź nakłonienie ich do określonego zachowania (Bóg czyni dobro, zanim jeszcze ktoś go o to poprosi). Modlitwa jest działaniem, które odbywa się na płaszczyźnie słów: wejściem człowieka w korelację z Bogiem ${ }^{12}$.

Po drugie, trzeba również się zgodzić, że w modlitwie dążymy do tego, by stać się przedmiotem myśli Boga. Clive Staples Lewis trafnie wyjaśnił, na czym miałoby to polegać. Otóż nie jest tak, że w Absolutnym Umyśle istnieją różne stopnie skupienia uwagi, a więc również nieuwaga, czyli coś w rodzaju roztrzepania. Zawsze całkowicie, a zatem zawsze tak samo, jesteśmy znani Bogu. Ale chociaż ta wiedza nigdy się nie zmienia, jakość „bycia poznanym” może ulegać zmianom. Być znanym Bogu oznacza być zaliczonym do kategorii rzeczy. Jesteśmy, podobnie jak zwierzęta, rośliny, wszechświat, przedmiotem Bożego poznania. Kiedy jednak stajemy się świadomi tego faktu i zgadzamy się całą swoją wolą na bycie poznanymi w ten sposób, wówczas zaczynamy traktować samych siebie, w odniesieniu do Boga, nie jako rzeczy, ale jako osoby. Zrzucamy zasłonę. Nie żeby jakakolwiek zasłona mogła przyćmić Jego wzrok. Zmiana dokonuje się w nas. Nie jesteśmy już bierni; stajemy się aktywni. Nie zadowala nas bycie poznanymi; zamiast tego pokazujemy się, mówimy, chcemy być na widoku. Zrywanie zasłon, wyznawanie grzechów i „przedstawianie” próśb pozwala nam odgrywać przed Bogiem zaszczytną rolę osób. Bóg do pewnego stopnia jest dla każdego taki, jaki ten ktoś jest dla Boga. Drzwi, które otwierają się dla niego w Bogu, są tymi, do których kołacze. Osoba w Nim spotyka się

11 A. J. Heschel, Cztowiek szukajacy Boga..., s. 49n.

12 R. Schaeffler, O języku modlitwy, Kraków 2007, s. 71. 
z tymi, którzy potrafią ją przyjąć albo przynajmniej przed nią stanąć. On mówi „Ja”, kiedy naprawdę zwracamy się do Niego „Ty”13.

Ale po trzecie, w pewnym sensie musimy przyznać rację Heschelowi, że nie zwracamy się do Boga w modlitwie jak osoba do osoby. Tyle że to wynika, jak się okazuje, z samej Klemensowej definicji modlitwy. Jak bowiem zauważa Józef Naumowicz:

Ta prosta formuła ujawnia swą głębię, jeżeli zwróci się uwagę na bogate znaczenie greckiego terminu homilia (przetlumaczonego tu jako „rozmowa”). Nie określa on jedynie słownego wyrażenia swoich myśli czy wymiany zdań. Oznacza także: obcowanie, spotkanie, miłosny dialog. Dlatego definicję modlitwy lepiej można przetlumaczyć jako „obcowanie z samym Bogiem”14.

I tak to sformułowanie jest rozumiane przez niektórych autorów, np. Simon Tugwell modlitwę określa tak: to przestawanie $z$ Bogiem ${ }^{15}$.

Jaką wobec tego, o ile w ogóle, otrzymujemy w tej rozmowie odpowiedź od Boga? A może jest to tylko owe wylanie serca, przestawanie z Bogiem, na które żadnej konkretnej odpowiedzi nie ma?

Według A. J. Heschela tą odpowiedzią Boga jest zainteresowanie naszym życiem, wejście w nie. Modlitwa nie kończy się na naszej aktywności, przedstawieniu się Bogu, staniu się osobą, jak powiedziałby C. S. Lewis:

Ale modlitwa nigdy się nie kończy, bo wiara darzy nas zuchwałym pragnieniem, by On zblizył się do nas i zwracał do nas jak ojciec - nie tylko jak władca; nie tylko przez to, że będziemy chodzić Jego drogami, ale także przez to, że On wkroczy na nasze drogi. Celem modlitwy jest przyciągnąć Jego uwagę, być wysłuchanym, być przez Niego zrozumianym; nie po to, by Go poznać, ale by być przez Niego poznanym. Modlić się to spostrzegać życie nie tylko jako skutek Jego władzy, ale także jako Jego troskę; modlić się to starać się uczynić nasze życie Bożą sprawą. Bo najwyższą aspiracją człowieka nie jest chęć, aby posiąść wiedzę, ale pragnienie, by stać się obiektem Jego poznania. Żyć ,w świetle Jego oblicza”, stać się myślą Bożą - oto prawdziwa kariera człowieka ${ }^{16}$.

Odpowiedź Boga zatem to nie słowa, ale Jego wkroczenie w nasze życie. Modlitwa, czyli ten swoisty dialog z Bogiem, powoduje więc powrót Boga do naszego świata, z którego został On wygnany:

Modlić się to przywracać Boga światu, to ustanawiać Jego królestwo, to umożliwić szerzenie się Jego chwały ${ }^{17}$.

13 C. S. Lewis, O modlitwie. Listy do Malkolma, Kraków 2011, s. 30-32.

14 J. Naumowicz, Tajemnica spotkania i mitości, (cyt. za: http://www.katolik.pl/tajemnica-spotkania-i-milosci,870,416,cz.html [dostęp: 23.07.2014]).

15 S. Tugwell, Modlitwa w bliskości Boga, Poznań 1988, s. 7.

16 A. J. Heschel, Cztowiek szukający Boga..., s. 50.

17 Ibidem, s. 102. 
Na tym jednak się nie kończy, bo modlitwa prowadzi też do rozumienia, jakiego nie można osiągnąć na innej drodze:

Co więcej, modlitwa może prowadzić do wglądu; często ubogaca nas rozumieniem, jakiego nie można by osiągnąć na drodze spekulacji. Nasze najgłębsze olśnienia, decyzje i postawy rodzą się w chwilach modlitwy. Często tam, gdzie zawodzi refleksja, sukces odnosi modlitwa. Tym, czym myślenie jest dla filozofii, modlitwa jest dla religii. Ale modlitwa może iść dalej niż spekulacja. Prawda świętości nie jest prawdą spekulacji - to prawda kultu ${ }^{18}$.

To ważne w świecie, w którym człowiek częstokroć żyje z dala od Boga i ten wydaje mu się całkowicie obcy i niezrozumiały.

Efektem dialogu z Bogiem nie są zatem stany mistyczne, w których następuje rozmowa $z$ Nim twarzą w twarz. A jednak nie jest to monolog, bo jego skutkiem jest odpowiedź Boga w postaci zainteresowania naszym życiem i naszą sprawą oraz nasze zainteresowanie sprawą Boga, zerwanie zasłony, stanie się osobą. Modlitwa niesie również poznanie Boga, jakie niemożliwe jest na drodze spekulacji. Nic więc dziwnego, że Heschel uważa, że modlitwa powinna przenikać całe nasze życie:

Czym jest micwa [oparte na Torze przykazania, których wypełnianie obowiązuje każdego dorosłego żyda - R. M. R.]? Modlitwą w formie czynu. A modlić się to odczuwać Jego obecność. „Poznaj Boga na wszystkich twoich drogach”. Modlitwa winna przenikać wszystkie nasze drogi. Nie musi być zawsze na naszych wargach; lecz musi być zawsze w naszych myślach, w naszym sercu ${ }^{19}$.

Zdaniem Heschela, człowiek jest zatem zdolny do dialogu z Bogiem, co więcej, tylko wtedy ma szansę ocalić swoje człowieczeństwo. Inaczej osuwa się w zło i bezprawie, co nie jest tylko konstruktem myślowym, ale znajduje potwierdzenie w historii. Co jednak tak istotnego Heschel wskazuje chrześcijańskiej antropologii?

\section{Wskazówki dla chrześcijańskiej antropologii}

Po pierwsze, istotnym składnikiem chrześcijańskiej antropologii powinno być przekonanie, że człowiek jest zdolny do dialogu z Bogiem. Nie jest to wskazanie oczywiste, jakby się na pierwszy rzut oka wydawało. Tak naprawdę we współczesnej antropologii teologicznej ten aspekt nie pojawia się bowiem bardzo często, a przynajmniej nie jest uznawany za najistotniejszy w określeniu człowieka ${ }^{20}$. W pracach Heschela znajdujemy solidne uzasadnienie - choć nie zawsze

$18 \quad$ Ibidem, s. 100 .

19 A. J. Heschel, Bóg szukający czlowieka..., s. 464.

20 K. Góźdź, Antropologia w relacji do teologii, „Teologia w Polsce” 4, 1 (2010), s. 90. 
wyrażone wprost - utrzymania tego przekonania, co więcej, uzasadnienie przekonania, że w żadnym razie antropologii nie wolno z tego aspektu zrezygnować. W pewnym sensie jego propozycja stanowi uzupełnienie podejścia K. Rahnera, który uważał, że człowiek „z natury” stoi przed Bogiem jako możliwy, przyjmujący podmiot teologii, mowy Boga, a wewnętrzne pozostawanie człowieka w relacji do formuły wiary, do Objawienia jest konieczne dla człowieka w jego byciu człowiekiem ${ }^{21}$. Człowiek nie jest tylko słuchaczem Słowa, bardziej niż słuchaczem jest mówiącym do Boga w modlitwie. Jego mowa ma przy tym moc przyciągania Boga do naszego świata, z którego został On wypędzony.

Po drugie, Heschel przekonująco pokazuje, że dialog (modlitwa) jest sposobem na wpuszczenie Boga do historii człowieka. Pozwala odzyskać więź z Bogiem, konstytutywną dla człowieka, bez której właściwie traci swoje człowieczeństwo. W świecie, w którym człowiek o więzi z Bogiem najczęściej w ogóle nie myśli, jest to cenne przekonanie. To ważna wskazówka dla antropologii teologicznej, która chce mówić o człowieku żyjącym wobec Boga. Owszem, w dialogu inicjatywa należy do Boga, to Bóg szuka człowieka, ale Heschel swoim rozumieniem modlitwy i dialogu człowieka z Bogiem przekonuje, że człowiek nie może pozostawać bierny.

Po trzecie, myśl Heschela skłania do wniosku, że modlitwa, ten szczególny akt relacji człowieka z Bogiem, dialogu z Nim, powinna stać się przedmiotem analiz w ramach antropologii teologicznej. Antropologia, która chce mówić o dialogu człowieka z Bogiem, o człowieku żyjącym wobec Boga, nie może pominąć tego ważnego aktu, który prowadzi do powrotu Boga do świata, konstytuującego ludzkie bycie człowiekiem. Wydaje się, że analiza tego aktu człowieka powinna zyskać pełnoprawne miejsce w antropologii teologicznej, nie zaś tylko w teologii duchowości. Modlitwa nie jest tylko dodatkiem do bycia człowiekiem, ona o tym byciu człowiekiem decyduje.

Po czwarte, Heschelowe spojrzenie na kwestię dialogu człowieka z Bogiem pozwala zrównoważyć skutki zwrotu antropologicznego w teologii. Heschel pokazuje, że owszem to w dużej mierze od człowieka zależy, czy przywoła Boga do swojego świata, ale to i Bóg odgrywa w tym znaczącą rolę, nie jest to skutek wyłącznie wysiłku człowieka. Bóg nie jest dodatkiem do antropologii, jest jej drugim (czy raczej pierwszym) biegunem obok człowieka.

$* * *$

Analiza myśli Heschela przekonuje, że istotnym momentem w dialogu człowieka z Bogiem jest modlitwa. Jest więc ona ważkim tematem dla antropologii teologicznej i powinna znaleźć w niej swoje miejsce. I to chcę właśnie $21 \quad$ Por. I. Bokwa, Wprowadzenie do teologii Karla Rahnera, Tarnów 1996, s. 94n. 
potraktować jako nieusuwalną treść chrześcijańskiej antropologii: przekonanie o zdolności człowieka do dialogu z Bogiem i przekonanie, że jej szczególny wyraz, modlitwa, jest tym, co powoduje powrót Boga do świata, z którego został wygnany.

Ujęcie Heschela ma też pewien aspekt praktyczny. Nie będzie wielkiego sensu, by antropologia teologiczna widziała człowieka jako zdolnego do dialogu z Bogiem w modlitwie, jeśli sama modlitwa nie będzie praktykowana, nie będzie jednym z najistotniejszych elementów życia chrześcijańskiego. Heschelowe charakterystyczne rozumienie dialogu człowieka z Bogiem w modlitwie (która nie jest monologiem, ale nie jest też rozmową) w czasach, gdy modlitwa przychodzi z trudem, wydaje się szczególnie cenne. Heschel dość skutecznie obala bowiem uproszczone widzenie modlitwy jako rozmowy z Bogiem zupełnie podobnej do rozmowy „przy kawie”. To prowadzi do tego, że Bóg nie jest tu traktowany jako bardzo bliski człowiekowi, przyjazny, rozmawiający z nim niczym kumpel z kumplem. Dla człowieka współczesnego, który nie wierzy w bliskość Boga, w jego często infantylne przedstawienia, przekonanie Heschela, że to, co człowiek może zrobić w modlitwie, to stać się przedmiotem Jego myśli, może okazać się bardziej przekonujące.

Słowa klucze: antropologia chrześcijańska, Abraham Joshua Heschel, modlitwa, dialog, rozmowa.

\section{Bibliografia:}

1. Bokwa I., Wprowadzenie do teologii Karla Rahnera, Tarnów 1996.

2. Góźdź K., Antropologia w relacji do teologii, „Teologia w Polsce” 4, 1 (2010).

3. Halkowski H., Posłowie ttumacza, w: A. J. Heschel, Panska jest ziemia. Wewnętrzny świat Żyda w Europie Wschodniej, Kraków 2010.

4. Heschel A. J., Bóg szukajacy człowieka. Podstawy filozofii judaizmu, Kraków 2007.

5. Heschel A. J., Człowiek szukający Boga. Szkice o modlitwie i symbolach, Kraków 2008.

6. Klemens Aleksandryjski, Kobierce.

7. Lewis C. S., O modlitwie. Listy do Malkolma, Kraków 2011.

8. Łuczewski M., Nowoczesna Zaglada (cyt. za: http://wyborcza.pl/magazyn/1,140258, 16547751,Nowoczesna_Zaglada.html [dostęp: 01.09.2014]).

9. Naumowicz J., Tajemnică spotkania i mitości, (cyt. za: http://www.katolik.pl/tajemnica-spotkania-i-milosci,870,416,cz.html [dostęp: 23.07.2014]).

10. Schaeffler R., O języku modlitwy, Kraków 2007.

11. Szczerbiński W., Abrahama Joshuy Heschela filozofia człowieka, Lublin 2000.

12. Tugwell S., Modlitwa w bliskości Boga, Poznań 1988. 